This item was submitted to Loughborough's Research Repository by the author.

Items in Figshare are protected by copyright, with all rights reserved, unless otherwise indicated.

\title{
South Asian American theatre: (un/re-)painting the town brown
}

PLEASE CITE THE PUBLISHED VERSION

http://journals.cambridge.org/action/displayJournal?jid=TSY

\section{PUBLISHER}

(c) Cambridge University Press for American Society for Theatre Research

\section{VERSION}

VoR (Version of Record)

\section{LICENCE}

CC BY-NC-ND 4.0

\section{REPOSITORY RECORD}

Chatterjee, Sudipto. 2019. "South Asian American Theatre: (un/re-)painting the Town Brown". figshare. https://hdl.handle.net/2134/6537. 
This item was submitted to Loughborough's Institutional Repository (https://dspace.lboro.ac.uk/) by the author and is made available under the following Creative Commons Licence conditions.

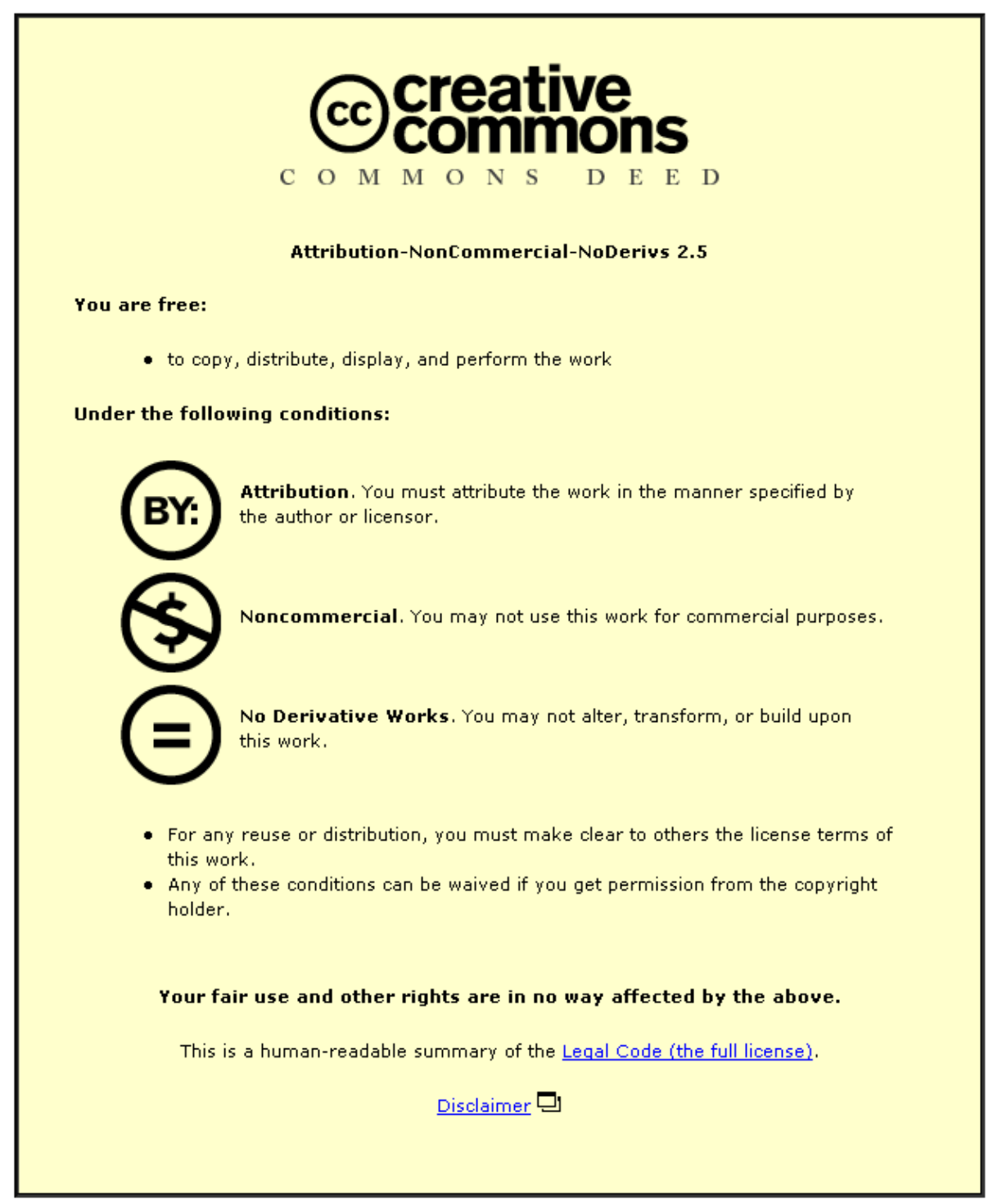

For the full text of this licence, please go to: http://creativecommons.org/licenses/by-nc-nd/2.5/ 


\section{Critical Stages EDITED BY MIKE SELL}

\section{Sudipto Chatterjee}

\section{SOUth ASIAN American TheATre: (UN/RE-)PAINTING THE TOWN BROWN}

In his second year at the University of California, Berkeley, Arthur William Ryder (1877-1938), the Ohio-born Harvard scholar of Sanskrit language and literature, collaborated with the campus English Club and Garnet Holme, an English actor, to stage Ryder's translation of the Sanskrit classic Mrichchhakatikam, by Shudraka, as The Little Clay Cart. ${ }^{1}$ The 1907 production was described as "presented in true Hindu style. Under the direction of Garnet Holme, who ... studied with Swamis of San Francisco ... [and] the assistance of many Indian students of the university." ${ }^{2}$ However, in the twenty-five-plus cast, there was not a single Indian actor with a speaking part. The intended objective was grandeur, and the production achieved that with elaborate sets and costumes, two live zebras, and elephants. Seven years later, the Ryder-Holme team returned with Ryder's translation of Kalidasa's Shakuntala, "bear cubs, a fawn, peacocks, and an onstage lotus pool with two real waterfalls." ${ }^{3}$ While the archival materials do not indicate the involvement of any Indian actors (barring one Gobind B. Lal, who enacted the Prologue), ${ }^{4}$ its importance is evinced by the coverage it received in the Oakland Tribune, the Overland Monthly and Out West Magazine, and the Los Angeles Times. ${ }^{5}$

Sudipto Chatterjee is a theatre scholar and performance maker. Currently teaching at Loughborough University in the U.K., he has taught at New York University, Tufts University, and University of California, Berkeley. His book, The Colonial Staged: Theatre in Colonial Calcutta, has been published by Seagull Books (2007). As theatre maker, he has directed Nuraldeen's Lifetime in New York and India. Most recently, he wrote and solo-performed Man of the Heart: The Life and Times of Lalon Phokir, which has been seen in California, New York, and India. As documentary maker, Chatterjee has recently completed Epic Women: Pandvani Solo-Performers of Chhattisgarh. 


\section{Theatre Survey}

Ryder's contributions to bringing Sanskrit theatre to America did not remain confined to the West Coast. The Progressive Stage Society had produced Ryder's translation of Shakuntala (spelled Sakuntala) in the Madison Square Garden Concert Hall on 18 June 1905, under the direction of Edmund Russell. Promotional reports note the use of "native Hindu music and native Hindu instruments. Native Hindus here are greatly interested and will aid the production, and some will take part." ${ }^{6}$ In 1919, Frank Conroy staged yet another production of the Ryder text at the Greenwich Village Theatre. In 1924, the progressive Neighborhood Playhouse of New York presented The Little Clay Cart for a seventy-two-show run (Fig. 1). Directed by Agnes Morgan and Irene Lewisohn, the production was hugely successful and remounted for a second run in 1926. Again, despite the theatre's liberal-minded choice, the goal was the grandeur of the mysterious East and the effect a one-way interpretation of a racial and cultural Other. Here, too, the actors were all non-Indian, all in "brown-face" as it were, barring two musicians, Arjuna Govind on the sitar and Sarat Lahiri on the esraj, although it is impossible to ascertain if they appeared onstage. Stark Young, the leading American theatre critic of the time, wrote:

This production of The Little Clay Cart is an interesting case of bona fide treatment when we come to foreign or classic plays. Any drama, obviously, Greek, Indian, French or Elizabethan, is alive for us only in so far as it still expresses life.... The necessity in every case of revival for production is to find a new form for it which does not violate the play but restates it under the conditions that are to be met. ${ }^{7}$

But the "conditions met" were nothing but the accoutrements of the Western stage, and the "restatement" was essentially a mystification of another lifestyle, culled to lull the spiritual thirst of the West.

One would hope that this would change over time, but it has not, and theatrical treatment of the East by the West remains largely informed by a colonial hierarchy of dominant and dominated cultures, if these days on a different, slightly more egalitarian scale. What was once an interest in producing "ancient" India has morphed into a more "contemporary" interest in the South Asia of today. However, in between the ancient and the contemporary, there were two world wars and the transitional years of colonial filmmaking — including both the many filmic iterations of Kipling's Jungle Book in Hollywood and the films of Merchant-Ivory-Jhabvala-which add a new dimension to how "India" is produced for popular Western culture. Such dimensions are apparent in Israel Horovitz's Obie Award-winning play The Indian Wants the Bronx (premiered at New York's Astor Place Theatre in 1968, under the direction of James Hammerstein, launching Al Pacino's career), in which Mr. Gupta, a newly arrived middle-aged Indian man looking for his son, gets pointlessly abused and tortured by two heedless white American youths. Horovitz's play would not function without Mr. Gupta, yet he is not the central character, merely an occasion for the violence of the white American youth. He speaks Hindi, but is neither understood by the characters nor by most of the non-Indian spectators, for the script leaves no provision for staging translation. Mr. Gupta is, if you will, absent in his 
Critical Stages

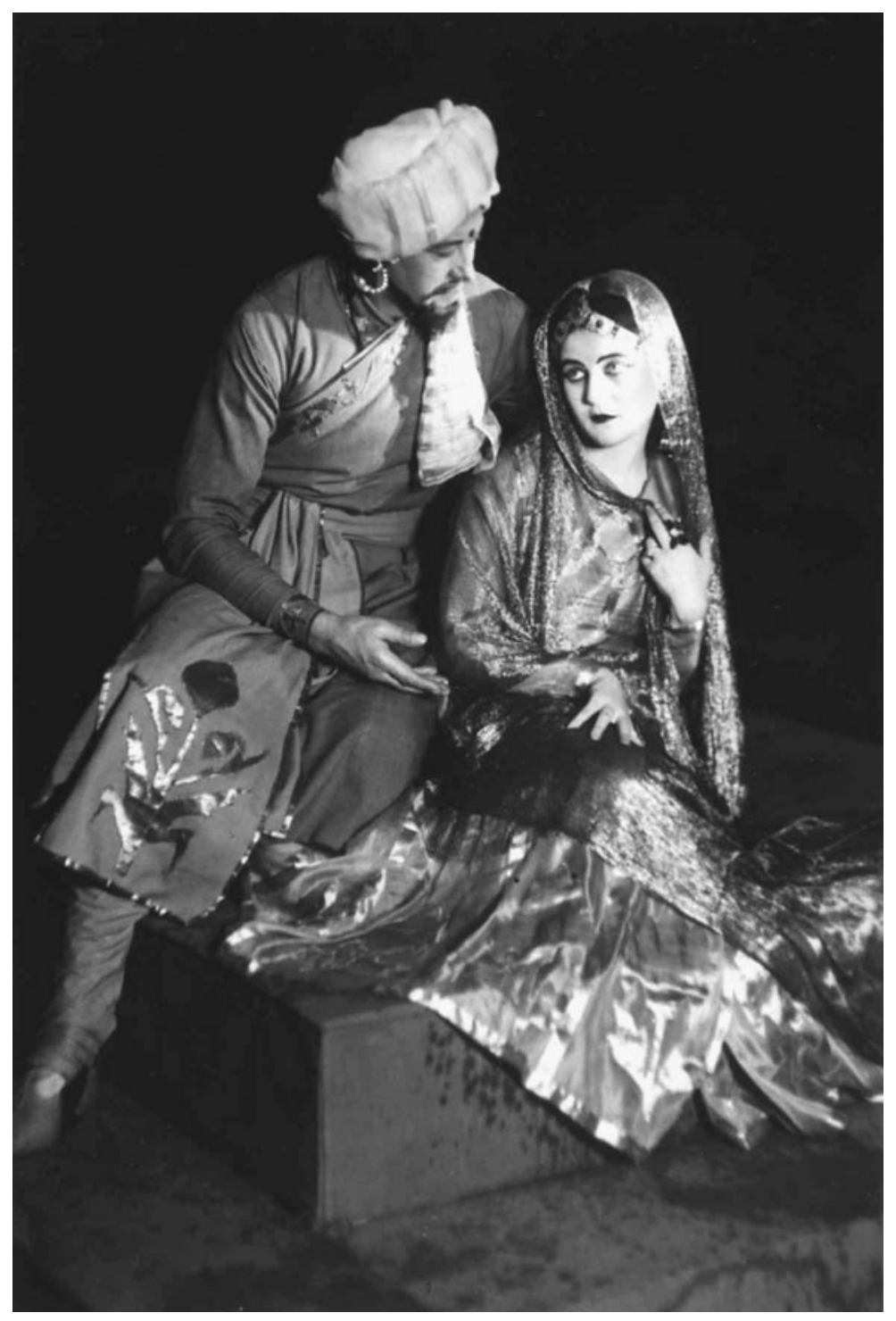

Figure 1.

Ian Maclaren and Kyra Alanova in the Neighborhood Playhouse (New York) production of Shudraka's The Little Clay Cart, 1924. Directed by Agnes Morgan and Irene Lewisohn. Photo courtesy of Neighborhood Playhouse Theatre School. 


\title{
Theatre Survey
}

presence, and the play, though ostensibly sympathizing with his hapless condition and pointless suffering, essentially renders him no more than a prop.

The Indian Wants the Bronx registers a different dimension of exoticization in which the depiction of rank poverty, civil rights gone remiss, blighted if melodramatized gender discrepancies, brave and exotic spiritual journeys in spite of squalor, and white superheroes saving blighted, brown souls all become hugely marketable commodities. This heady mix of exoticization, conscience-pricking, and "authentic casting" represents the "Third World," as Vijay Prashad argues, as a project, not necessarily a place. ${ }^{8}$ Western cinema has developed an identifiable subgenre in this area too, starting with films like Jean Renoir's The River (1951), Octopussy (John Glen, 1983), Passage to India (David Lean, 1984), Indiana Jones and the Temple of Doom (Steven Spielberg, 1984), Salaam Bombay (Mira Nair, 1988), City of Joy (Rolland Joffé, 1992), and, most recently, Born into Brothels (Ross Kauffman and Zana Briski, 2004) and The Darjeeling Limited (Wes Anderson, 2007). The theatrical counterpart would be blockbuster productions like Bombay Dreams (2002), produced by Andrew Lloyd Webber, with music by A. R. Rahman, the most popular film composer in India. Although the cast has consistently drawn from local South Asian talent pools where it is produced, it is very much a Webber musical, drawing tropes as well as plot formulae from Hindi cinema, a.k.a. "Bollywood." Tanya Shaffer's Baby Taj (directed by Matt August), which opened in San Jose's TheaterWorks in 2005, received warm reviews, but one of them could have been written a hundred years ago:

\begin{abstract}
Using an ingenious blend of scenic options, ... [the] set design maintains the visual motifs without reproducing replicas-curves where Western architecture would use angles; teardrops, spirals, crescents. Composite structures, part painted drop, part fly, part set piece, help turn the Taj Mahal into a living room quicker than you can say, "Bollywood dance tunes".... And so many creative uses of silks! ${ }^{9}$
\end{abstract}

The one factor causing a few dents in the aesthetic edifice surrounding South Asia is the presence of South Asian artists working internationally, be it from inside South Asia or across the South Asian diaspora. South Asian artists have gained more visibility in American theatre compared to the early twentieth century, when they were not seen as much more than the zebras, peacocks, and bear cubs. Furthermore, these artists are voicing their concerns with increasing alacrity, coming together under the self-proclaimed umbrella of "Desi" again, there are several complexities, not the least of which is Eurocentrism. The South Asian often ends up regurgitating and reinforcing Orientalist stereotypes.

So, this brings us to a point where we need to break down the term "South Asian American," which, like all such designations, operates at multiple levels. ${ }^{11}$ In the context of theatre, the term "South Asian" can be put into three discrete categories:

1. South Asian community performances (in a variety of languages) made by and for South Asian American communities. 
2. Visiting South Asian performers (using a variety of languages) in America.

3. South Asian American performances by the grown descendants of immigrants, often in collaboration with other ethnic communities and mainstream culture.

While the above categorizations can apply to many other North American ethnic communities, the South Asian category is historically and culturally specific. Foremost, there is the issue of subethnicities and subnationalities, usually clumped together in mainstream Anglo-U.S. culture and, to some extent, even in academia. This can further distance South Asia and South Asians through internal divisions between ethnic groups and languages, resulting in insular performances. This impacts academic writing on South Asian performance as well, because it is often difficult to work across the enormous ethnodemographic range of region-based subcontinental cultures, yet publishers are often wary of "overspecialized" studies. Consequently, cultural activities within these communities—and scholarship within specializations, as well—can become incestuous and repetitive.

Meanwhile, community performances have become dependent on a sentimental nostalgia for "home." But nostalgia for what? In the Bengali community, the one I know best, most organizations will choose to perform only imported plays - say, by Manoj Mitra or Badal Sircar, if the group is from West Bengal, or plays by Syed Shamsul Haq or Munir Choudhury, if the group is Bangladeshi. At best, it might be a play written by a local writer trying his or her hand with subjects that are familiar to the community. On top of that, in the name of nation and faith, there is little love lost between Indian Bengalis and Bangladeshis, despite their common language; the same goes for the Punjabi and Sindhi communities, fractured between national allegiances to India or Pakistan. This spells doom in the larger scenario, for the South Asian American communities fail not only to relate to the mainstream, but fall short in relating even to themselves. Thus, the diasporic community in its formative first generation fails to see itself within the mainstream, and all that is left is to create a simulacrum of a nostalgic past. This void in community performance leads invariably to tours of performers and companies from "home"-stars, both old and new, actors, musicians, you name them. ${ }^{12}$ The traveling performers add to the memory archive of the diasporic community and create a new bridge to "home," but, more often than not, be it on account of low budgets or lack of context, the performances are diluted versions of what would be presented for audiences in South Asia. There is joy when an actor whips out a South Asia-made matchbox to light a cigarette!

The onus of this multilayered problem has to be shifted from the immigrant South Asian to their first-generation American progeny. But they, too, have been raised torn between their parents' cultures and what they are told by the mainstream is their culture. Many among this first generation rejected their parents' cultures as children and found comfort in conformity with mainstream Anglo-American culture. However, almost all, at some point, are confronted with the reality of their pigmentation and the normative pressures from the mainstream 


\section{Theatre Survey}

to live up to their racial/ethnic difference, forced to declare it like one has to at immigration and customs checkpoints. This, in many cases, causes a broader reconsideration, and many first-generation South Asian Americans, artists in particular, take a turn to face their ancestry on different terms. Ultimately, it is in their embodied existence that South Asian Americanness begins to find shape. This development has accelerated since 9/11 and the promulgation of the Patriot Act, which has underscored "brownness" as a checkpoint of racial otherness.

When it comes to the first generation of America-born South Asians, the tendency is for a new kind of critical and experiential interculturality. This is evident in the work of artists and writers like Aasif Mandvi, Shishir Kurup, the comedian Alladin, and Rehana Mirza; groups like Desipina \& Company or SALAAM Theatre in New York, SAATh in the Boston area, Rasaka Theatre Company in Chicago, and Rasik Arts in Toronto; and arts organizations like the Indo-American Arts Council, Inc. in New York. Only through collusion with first-generation artists can truly interesting theatre emerge. Middle spaces, interstitial habitats, and complex and layered levels of hybrid expressivity must be found for South Asian American theatre to flourish. Along with the artists are a growing number of academics of South Asian descent and/or specialization who are trying to change the status quo in their own ways, among them James Brandon, Farley Richmond, Darius Swann, Phillip Zarrilli, Vasudha Dalmia, Richard Schechner, Una Chaudhuri, Aparna Dharwadker, Philip Lutgendorf, Susan Seizer, Nandi Bhatia, Fawzia Afzal Khan, David Mason, Jyotsna G. Singh, and Rakesh Solomon of the earlier generation, and Erin Mee, Avanthi Meduri, Ananya Chatterjea, Jisha Menon, Neilesh Bose, Kristin Rudisill, Avishek Ganguly, Charlotte McIvor, and Ayan Gangopadhyay among the younger scholars. These have demonstrated that both theatre and theatre scholarship must engage these complex intersections in the deepest possible way, resisting the harm fluffy blockbuster productions like Bombay Dreams inflict.

A case in point would be Houston's Shunya Theatre's 2004 mounting of Horovitz's Indian Wants the Bronx. Under the direction of Guru Singh, live performance in this production is interjected, according to the official press release, with "a montage of images depicting the struggles, the successes, and the hope of the South Asian American immigration experience." Taken from a documentary film directed by Sameer Vyas, these images, "interwoven throughout the production," feature "answers given by local immigrants interviewed about their own personal experiences after arriving in the United States. Why did they come? What challenges have they faced? Is America truly the land of opportunity?"13 The issue of immigration is not unique to the South Asian community, of course, nor the complications it injects into theatre and scholarship. But compared to South Asian Americans, East Asian American communities, for example, have the vantage of a greater presence in mainstream American culture, thanks largely to the U.S. West Coast's proximity to East Asia. This impacts the "Asian American" theatre scenario in an interesting way, placing South Asian American theatre in a double bind. It must struggle both with and within its already divided communities as it negotiates a place within the larger Asian American assemblage. East Asian American theatre has created its 
own place in mainstream American theatre and a roster of prominent playwrights, including David Henry Hwang, Philip Kan Gotanda, Han Ong, Ping Chong, Jessica Hagedorn, and so on. However, South Asian American theatre has not (yet) had its messianic playwrights nor significant mainstream impact. Already dealing with the fractures of language, religion, and culture within its own demography, South Asian American theatre is a double minority as part of the Asian American minority.

In response to this condition, Shishir Kurup, South Asian American actor-director-writer-musician, has been working with the Cornerstone Theatre Company in Los Angeles to build bridges between different ethnicities and marginalized communities, Asian American as well as others. His intriguing adaptation of Shakespeare's Merchant of Venice, retitled Merchant on Venice, is an excellent example of this new development in South Asian American performance. Picked up for production in 2007 by Silk Road Theatre Project in Chicago under the direction of Stuart Carden (Fig. 2), the drama is transplanted from Italy to the multiethnic Venice Boulevard area of Los Angeles. "And you thought this was a story of Renaissance-era Venice, where rich Christian businessmen crassly used, abused and finally destroyed the Jew who lived among them. Think again," writes Hedy Weiss for the Chicago Sun-Times:

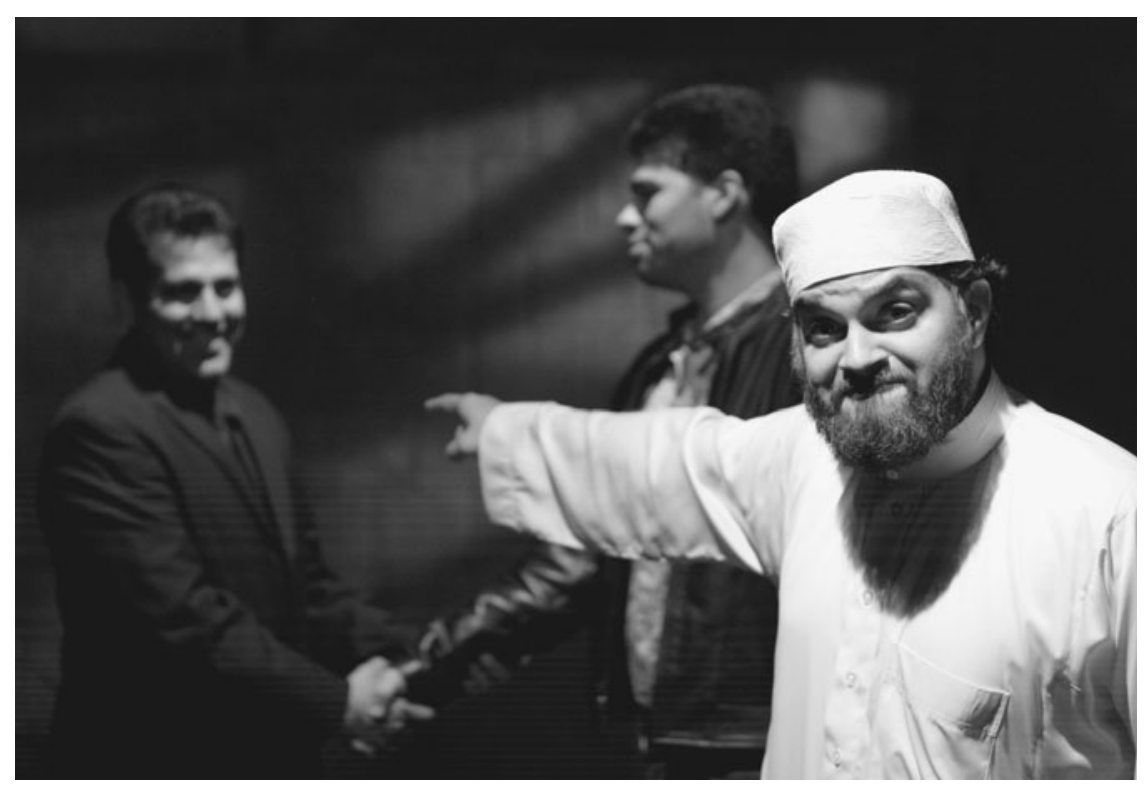

Figure 2.

Kamal Hans (left), Andy Nagraj (center), and Anish Jethmalani (right) in the Silk Road Theatre Project (Chicago) world premiere of Shishir Kurup's Merchant on Venice, 2007. Directed by Stuart Carden. Photo by Johnny Knight, courtesy of Silk Road Theatre Project. 


\section{Theatre Survey}

Kurup (born in India, raised in Kenya, a longtime transplant to the United States), has a Salman Rushdie-like fluency in cross-cultural, pop-cultural hijinks and a flair for highly ornamented, wildly comical linguistic flights. And, in updating his Merchant to contemporary Venice, Calif.-where wealthy, worldly Hindus face off against a prosperous, ultra-conservative Muslim - he has heightened the controversy for our times and conjured a feast of behavioral and musical correspondences that do Shakespeare proud. ${ }^{14}$

In the same review, Weiss recommends the show for a more mainstream pickup by the Public Theater in New York: "Stage this production at the outdoor Delacorte Theater and you can bet half the Indian immigrant population of Queens will be lined up for seats, with the Muslims of Brooklyn right behind them."

Sudipta Bhawmik, a prolific playwright, believes that,

[i]n parts of the country, the South Asian population has reached the critical mass to be able to sustain a South Asian-only kind of theatre and arts.

Besides, the children of the first-generation South Asian immigrants are also eager to establish their own identity and are choosing South Asian theatre, film, and the arts as their medium of expression. Hence, South Asian theatre in America is transitioning from a crossover genre to a more mainstream art form (even while retaining its ethnic identity). ${ }^{15}$

Without this osmosis between the generations and their combined interaction with the U.S. mainstream and other ethnic communities, South Asian American theatre will continue to amputate its own validity and reproduce the same old archived and dead memories, colonial stereotypes, and demeaning images. Aparna Dharwadker has claimed that original theatre cannot emerge in diaspora unless "it distances itself from the culture of origin and embraces the experience of residence in the host culture, with all its attendant problems of acculturation and identity." 16 Desi theatre will mean nothing unless self-interrogated stringently and more creatively, making it worthwhile for all sorts of audience, not merely the diasporic. It is only this emergent theatre that may dislodge the Orientalism that permeates contemporary representation of South Asia in mainstream U.S. theatre, whether they are productions of the "India" plays of Tom Stoppard or Terrence McNally, or trite entertainments like Tanya Shaffer's Baby Taj. It's time to attack, change, and problematize that. South Asian American theatre needs to stand on its own merit. Samrat Chakrbarti, South Asian American actor and composer based in New York, working hard between the two coasts, speaks passionately on the subject:

The bottom line is, yes, we have progressed since ten years ago, but we have a long way to go. Producers must start making more courageous color-blind choices. Writers have to write more three-dimensional characters for South Asians. Right now there aren't enough people behind the scenes, i.e., casting directors [to promote us]. So, even if American theatre companies do produce 


\section{Critical Stages}

South Asian-themed plays, they lack authenticity. As artists and South

Asians, we must organize our voices so we can paint the town brown. ${ }^{17}$

\section{ENDNOTES}

1. In the nineteenth and early twentieth centuries, none of the English translators of Sanskrit plays was from India. Euro-American Indologists had absolute supremacy in this area, although there were many Indian scholars who translated from the Sanskrit into local regional vernaculars.

2. "Programs in the Greek Theatre," University Archives, The Bancroft Library, University of California, Berkeley.

3. Marcus Wohlsen, "The Greatest Show on Earth," Illuminations (October 2005), online at illuminations.berkeley.edu/archives/2005/history.php?volume $=9$ (accessed 5 December 2007).

4. "Greek Theatre Events, 1903-24: English Club Productions," University Archives, The Bancroft Library, University of California, Berkeley.

5. Wohlsen mentions a preview of the performance that appeared in the Los Angeles Times in 1914, as well as a review published by the Overland Monthly and Out West Magazine.

6. "To Produce Sanskrit Play," New York Times, 4 June 1905, X4.

7. Stark Young, "The Little Clay Cart," New York Times, 14 December 1924, X3.

8. Vijay Prashad, The Darker Nations: A People's History of the Third World (New Delhi: LeftWord Books, 2007).

9. Marianne Messina, Review of Baby Taj (dir. Matt August), Metroactive (Silicon Valley weekly), 5-11 October 2005; online at www.metroactive.com/papers/metro/10.05.05/baby-taj0540.html (accessed 29 January 2008).

10. Colloquial Hindi word meaning "of the land." Desh, in Sanskrit, means "homeland." Although in use since the 1980s, this term has gained much currency among second-generation South Asian Americans for identifying themselves.

11. The ensuing discussion draws to a great extent from a panel on South Asian American performance organized as part of Asia: By Means of Performance at UC Berkeley's Department of Theater, Dance, and Performance Studies in 2006, under the aegis of the University of California's systemwide Multi-Campus Research Group on Globalization and International Performance. The panel comprised both theatre practitioners from South Asian communities in Northern California and academics specializing in South Asian performance, including myself, Sujit Saraf, Vidhu Singh, Sambit Basu, and Charlotte McIvor.

12. While these concerts are also divided along lines of community, faith, and nationality, it is interesting to note that Bollywood stars have a power to bring South Asians from all communities out together.

13. Meha Gargi, "Shunya Brings 'The Bronx' to Houston," Shunyatheatre.org, 17 July 2004, online at www.shunyatheatre.org/news7-17-04.htm (accessed 4 December 2007).

14. Hedy Weiss, "Worldly Hindus Take on a Strict Muslim: Take Another Look at the Bard's 'Merchant," Chicago Sun-Times, 1 October 2007, online at srtpblog.blogspot.com/2007/10/merch ant-on-venice-is-highly.html (accessed 29 January 2008).

15. Sudipta Bhawmik, interviewed electronically by the author, 2 December 2007.

16. Aparna Dharwadker, "Diaspora and the Theatre of a Nation," Theatre Research International 28.3 (October 2003): 303-25.

17. Samrat Chakrbarti, interviewed electronically by the author, 2 December 2007. 